\title{
The Addition of Jamu Lempuyang (Zingiber Zerumbet Herbs) in Chicken Feed toward the Condition of the Nutrition Digestibility of Free-Range Chicken
}

\author{
Wahyu Widodo \\ Univ. of Muhammadiyah Mlg \\ wahyu@umm.ac.id
}

\author{
Imbang Dwi Rahayu \\ Univ. of Muhammadiyah Mlg \\ dwirahayuimban@gmail.com
}

\author{
Adi Sutanto \\ Univ. of Muhammadiyah Mlg \\ sutantoadi@yahoo.com
}

\begin{abstract}
The purpose of this research was to analyze the effect of adding jamu lempuyang into the chicken feed toward crude fiber digestibility, fat digestibility, protein biological value and nitrogen retention of free-range chicken. This research used experimental method. The design used in this study was completely randomized design (CRD) with 4 treatments and 5 replications. The treatment in this study consisted of P0 without Zingiber (as a control), P1 Zingiber $0.15 \%, P 2$ Zingiber $0.30 \%$, and P3 Zingiber $0.45 \%$. The variables measured were crude fiber digestibility, fat digestibility, protein biological value and nitrogen retention of free-range chicken. The data were analyzed by using analysis of variance (ANOVA). When there was a significant effect, it was further tested by using Least Significant Difference (LSD). Based on the research, the effect of adding jamu lempuyang into the feed was not significant $(P>0.05)$ on crude fiber digestibility, protein biological value and nitrogen retention of free-range chicken. On the other hand, the effect of adding jamu lempuyang into the feed had significant effect $(P<0.05)$ on fat digestibility. Jamu lempuyang on free-range chicken was less effective in increasing crude digestibility protein biological value and nitrogen retention but more effective to increase fat digestibility of freerange chicken.
\end{abstract}

Keywords: nutrition condition, organic food ingredients, herbs, lempuyang

\section{INTRODUCTION}

Free-range chicken as one of the consumer choices has some advantages compared to broiler. The chickens have high adaptability to adjust to various situations, environmental conditions, climate changes, and local weather. But there is no standard guidance about the requirement of chicken feed for free-range chicken so the productivity is not optimal yet. One effort to spur the growth and productivity of free-range chicken is by using herbs. Many herbs are used as additional chicken feed ingredients found in Indonesia that have the potential to be used as additives. Generally, in herbs (rhizomes, leaves, stems, roots, flowers and fruits), there are active compounds such as alkaloids, phenolic, tripenoid, glycosides and so on as antiviral, anti-bacterial and immunomodular. One of the herbs is jamu lempuyang.

Lempuyang (Zingiber zerumbet Linn) can stimulate digestion and improve the efficiency of chicken feed. Compounds contained in lempuyang are flavonoids and essential oils. These compounds have antiviral and antibacterial ingredients that can inhibit Salmonella sp in the digestion [1]. If Salmonella sp. decreased in the digestion so it can increase the digestibility level. Essential oils stimulate the production of digestive juices that produce $\mathrm{pH}$ suitable for digestive enzymes. At the same time, there is an increase in the activity of digestive enzymes and the regulation of microbial activity. [2]-[5].

We can analyze the digestive usefulness by some ways such as crude fiber digestibility, fat digestibility, and protein digestibility. The biological value of the protein is calculated from some of the absorbed nitrogen proportions that the body can utilize. The requirement and quality of the protein can also be measured from the nitrogen balance. Poorer quality protein will excrete more nitrogen. It is necessary to conduct research on organic feed with the addition of herbs especially lempuyang with the title of "The Effect of Jamu Lempuyang (Zingiber Zerumbet Herbs) in the Organic Chicken Feed Towards The Condition of Nutrition Digestibility of Free-range Chicken".

The problem statement: is there any effect of jamu lempuyang (zingiber zerumbet herbs) in the organic chicken feed towards the condition of nutrition digestibility of free-range chicken? Meanwhile, the research purpose is to analyze the effect of jamu lempuyang (zingiber zerumbet herbs) in the organic chicken feed towards the condition of nutrition digestibility of free-range chicken.

\section{METHOD}

This research was conducted in Tegalgondo Village, Karangploso District, Malang Regency. This research was conducted in January - May, 2017. This study used 100 chickens. Those chickens were reared for 63 days. In this study, the litter system enclosure of the cages was utilized. This research used experimental method. The design used in this study was completely randomized 
design (CRD) with 4 treatments and 5 replications. The treatment in this study consisted of P0 without Zingiber (as a control), P1 Zingiber $0.15 \%$, P2 Zingiber $0.30 \%$, P3 Zingiber $0.45 \%$. The variables measured were crude fiber digestibility, fat digestibility, protein biological value and nitrogen retention of free-range chicken. The nutritive contents were analyzed by proximate analysis in the Nutrition Laboratory of University of Muhammadiyah Malang. The data were analyzed by using analysis of variance (ANOVA), when there was a significant effect, it was further tested by using Least Significant Difference (LSD).

\section{RESULTS}

The results of the effect of jamu lempuyang in chicken feed toward the condition of nutrition digestibility consisting of crude fiber digestibility, fat digestibility, protein biological value, and nitrogen retention of free-range chicken showed varying results as contained in Table 1.

Table 1. Condition of Nutrition Digestibility of Free-range Chicken

\begin{tabular}{|c|c|c|c|c|}
\hline \multirow[b]{2}{*}{ Treatment } & \multicolumn{2}{|c|}{ Nutrition Digestibility (\%) } & \multirow[b]{2}{*}{$\begin{array}{c}\text { Protein } \\
\text { Biological Value }\end{array}$} & \multirow[b]{2}{*}{$\begin{array}{l}\text { Nitrogen } \\
\text { Retention } \\
\end{array}$} \\
\hline & $\begin{array}{cc}\text { Crude } & \text { Fiber } \\
\text { Digestibility } & \\
\end{array}$ & $\begin{array}{c}\text { Fat } \\
\text { Digestibility }\end{array}$ & & \\
\hline $\mathrm{P} 0$ & 22,70 & 66.36 & 36,72 & 0,38 \\
\hline $\mathrm{P} 1$ & 19,42 & 68.81 & 34,43 & 0,34 \\
\hline $\mathrm{P} 2$ & 22,30 & 69.61 & 32,10 & 0,29 \\
\hline P3 & 17,20 & 69.38 & 34,79 & 0,35 \\
\hline
\end{tabular}

The calculation showed the addition of jamu lempuyang in the feed had no significant effect ( $p>0.05$ ) on the crude fiber digestibility of free-range chicken. Chicken feed ration has similarly crude fiber content, resulting in equal crude fiber digestibility. The essential oil content in lempuyang is able to degrade the amount of Salmonella Sp. in the gastrointestinal tract, but is not yet optimal to improve the digestibility of crude fiber. This is due to the amount of nutrient content during the maintenance which is relatively similar, like crude fiber which is about 3.30 percent. [6] The high content of crude fiber has a negative impact on energy metabolism. If the polysaccharides in crude fiber cannot be digested, it will decrease the energy availability in the ration and the metabolic energy and vice versa [7].

The calculation showed the addition of jamu lempuyang in the feed had significant effect $(\mathrm{p}<0.05)$ on the fat digestibility of free-range chicken. The results of the least significant difference (LSD) showed fat digestibility in the treatment of $\mathrm{P} 2$ and $\mathrm{P} 3$ was lower than that of $\mathrm{P} 0$ and $\mathrm{P} 1$, this is because the essential oil content in lempuyang can increase the metabolism of the fat. Lempuyang contains flavonoids, allicin, and essential oils that will stimulate the performance of enzymes that process synthesizing cholesterol and fat and fatty acids. The enzyme includes tri-hydroxy tri-mrthyl glutaril, coenzyme A-reductase and cholesterol $\alpha$ hydroxylase. Fat is metabolized by the body to degrade Salmonella sp, thus it affects the fat digestibility. Giving lempuyang containing essential oils will improve the work of poultry digestive organs, stimulate the bile wall to removes bile and stimulate the release of pancreatic sap containing lipase, amylase and protease enzymes. The lipase enzyme will digest triglycerides into the mono glyceridase fatty acids, and the pancreas interact with bile salts to form micro particles that dissolve the fat digestive product [8].
The calculation showed the addition of jamu lempuyang in the feed had no significant effect ( $\mathrm{p}>0.05)$ on the protein biological value of free-range chicken. This is due to the protein levels contained in the diet at each treatment is relatively the same during the maintenance, as much as 20 percent. Consequently, the level of the protein is digested equally so that the biological value of the protein at each treatment is the same. The remaining unused protein content in the body will be discarded trough cloacae. Chickens do not remove the urine liquid because the urine in the chicken flows into the cloacae and is issued together with feces. During the digestion process, the protein of the consumed feed is broken down into different amino acids [9]-[10]. One of the important nutrients for the growth of livestock is protein, because if the livestock lacks protein then the growth is disrupted. [11] states the digestibility of protein depends on the protein content in the ration. Rations, that have low protein content, generally have low digestibility and vice versa.

The calculation showed the addition of jamu lempuyang in the feed had no significant effect ( $\mathrm{p}>0.05$ ) on the nitrogen retention of free-range chicken. This is due to the quantity and quality of the same protein content in each treatment that cause the chicken to consume the feed with the same quantity and quality so that the digestibility level does not increase. The addition of lempuyang can inhibit the growth of Salmonella sp. because it contains flavonoids and essential oils, but still has not increased nitrogen retention. Nitrogen retention was not significantly influenced by ration pattern factors, starter age or sex [12]. [13] stated, nitrogen retention value at treatment $\mathrm{R} 1$ is very significantly higher than $\mathrm{R} 2, \mathrm{R} 3$ and $\mathrm{R} 4$. The high nitrogen retention in $\mathrm{R} 1$ indicates that the feed quality without the addition of fish silage starch is better than that of fish containing fish silage flour, either $60 \%, 80 \%$ or $100 \%$ fish meal starch. It 
also identifies that the quality of $\mathrm{R} 1$ protein is better than that of R2, R3 and R4. [14] states that the quality of feed protein depends on the amino acid composition and also depends on how the amino acids are used by the animals. Nitrogen retention depends on nitrogen consumption and metabolic energy rations, but increased metabolic energy rations are not always followed by increased nitrogen retention. The icreasing nitrogen consumption is followed by the increasing nitrogen retention but is not always accompanied by the increasing body weight when the ration energy is low [15]. The higher the amount of the protein consumed, the higher the protein content released by urine and feces. The amount of nitrogen in proteins which can be retained and used by livestock is called nitrogen retention [16]. Nitrogen retention can be either positive or negative. It is influenced by nitrogen consumption, but the increasing nitrogen consumption is not always accompanied by the increasing body weight [14]. At the same level with protein, weight gain increases with the increasing energy in the ration [13]. When the consumed nitrogen is greater than the excreted nitrogen, the chicken is in a positive nitrogen retention state and vice versa. Negative nitrogen retention is shown by the decreasing body weight, especially if the energy in the ration is high [14].

\section{CONCLUSION}

Based on the results of the research, the addition of jamu lempuyang in the feed as much as $0.15-0.45$ percent has no significant effect on the crude fiber digestibility, protein biological value and nitrogen retention of freerange chicken meat but has significantly affected the fat digestibility of free-range chicken. Also, the best treatment that can increase fat digestibility is the addition of lempuyang, by $0.00 \%$ and $0.15 \%$

\section{ACKNOWLEDGEMENTS}

Our gratitude is devoted to Ministry of Research and Technology and Higher Education, for funding this research. Our gratitude is also directed to Directorate of Research and Community Service University of Muhammadiyah Malang for the opportunity to carry out this research.

\section{REFERENCES}

[1] Suhirman, S., Hernani dan Cheppy, S. Uji Toksisitas Ekstrak Lempuyang Gajah (Zingiber zerumbet) terhadap Larva Udang (Artemia salina Leach.). Buletin Littro. Vol. XVII No. 1, 2006, 30 38. 2006.

[2] Bintang, I. A. K. dan Nataamijaya, A. G. Karkas dan Lemak Subkutan Broiler yang Mendapat Ransum dengan Supplementasi Tepung Kunyit (Curcuma domestica Val) dan Tepung Lempuyang (Zingiber aromaticum Val). Seminar Nasional Teknologi Peternakan dan Veteriner. Bogor.
Puslitbang Peternakan, Bogor. Halaman 623-628. 2006.

[3] Lee, K. W, Everts, H. and Beyne, A. C. 2004. Essentials Oils in Broiler Nutrition.International Journal of Poultry Science 3 (12): 738 - 752. 2004.

[4] Horosova, K., Bujnakova, D., and Kmet, V. 2006. Effect of Oregano Essential Oil on Chicken Lactobacilli and Escherichia Coli. Bulletin Folia Microbiol. 51 (4) Halaman 278-280 tahun 2006.

[5] Nursal, Wulandari S., dan Juwita W.S. Bioaktivitas Ekstrak Jahe (Zingiber officinale Roxb.) dalam Menghambat Pertumbuhan Koloni Bakteri Escherichiacoli dan Bacillus subtilis. Jurnal Biogenesis Vol. 2 (2) : 64-66. 2006.

[6] Elvina. Kadar Lignin dan Serat Kasar Untuk Metabolisme Ternak Ayam.Jurusan Ilmu Nutrisi dan Makanan Ternak.Fakultas Peternakan.Universitas Jenderal Soedirman. 2008.

[7] Widodo, W. Nutritive Content Assessment Organic Feedstuff Various Regions East Java Province Indonesia Potential Exploration Efforts Local Poultry Feed. http://www.innspub.net/ijb/. Vol 12 (3). 18-23, March 2018. 2018.

[8] Jarmani, Pengaruh Penambahan Lempuyang (Zingiber Zerumbet) dalam Pakan Terhadap Penampilan Produksi Ayam Pedaging. Yogyakarta: Universitas Gadjah Mada 2016.

[9] Suprijatna, E. Pengaruh protein ransum saat periode pertumbuhan terhadap performans produksi telur saat periode produksi pada ayam ras petelur tipe medium. J.Indon.Trop.Anim.Agric. Fakultas Peternakan Universitas Diponegoro. Semarang. 2005.

[10] Riyanto, I. Analisis Kadar, Daya Cerna dan Karakteristik Protein Daging Ayam Kampung dan Hasil Olahannya. Skripsi. Program Studi Teknologi Hasil Ternak, Fakultas Perternakan. Institut Pertanian Bogor. 2006.

[11] Ranjhan, Animal Nutrition In Tropics. Vkas. Publishing House Pvt. Ltd. Sahibabad, Ghaziabad, P:335. 1980.

[12] Sofjan, I., P. Handayani dan D. Sudrajat. Retensi Energi Dan Nitrogen Dan Laju Pencernaan Pada Ayam Silangan Pelung X Kampung Pada Pola Pemberian Ransum Dengan Protein Berbeda. Balai Penelitian Ternak. Bogor. 2001.

[13] Maulana, I. Nilai Retensi Nitrogen Pada Ayam Kampung Umur 12 Minggu Yang Diberi Pakan Mengandung Tepung Silase Ikan. Skripsi. 
Fakultas Peternakan. Institut Pertanian Bogor. 2008.

[14] Widodo, W. Ilmu Nutrisi Ternak Unggas. Fakultas Pertanian Peternakan. UMM Press, Malang. 2015.

[15] Sofiati, E. A. M. R. Metabolisme Energi dan Retensi Nitrogen Broiler Pasca Perlakuan Ransum Mengandung Tepung Daun Jarak Pagar (Jatropha
curcasL.). Skripsi. Program Studi Ilmu Nutrisi dan Makanan Ternak. Fakultas Peternakan. Institut Pertanian Bogor. 2008.

[16] Sibbald, I. R. And M. S. Wolynetz. Relationship between apparent and true metabolizable energy and the effect of nitrogen correction. J Poult Sci. 63:1386-1399. 1984. 